\title{
ELITE COMPETITION AND CHANGING STATE-SOCIETY RELATIONS: SHARI'A POLICYMAKING IN INDONESIA
}

\author{
Michael Buehler ${ }^{1}$
}

Since the New Order collapsed in 1998, scholars have tried to characterize the "deep architecture" of politics in Indonesia. ${ }^{2}$ This search for patterns in the accumulation and exercise of power has centered around the question of whether ancien régime figures continue to dominate politics or whether groups that were marginalized during the dictatorship have gained influence. Vedi Hadiz, Richard Robison, and Jeffrey Winters, who argue that a small group of wealthy individuals rooted in the New Order regime continue to define politics in contemporary Indonesia, have made an important contribution to this debate. ${ }^{3}$ This "oligarchy thesis" has been influential for many scholars of Indonesian democracy, yet its focus on wealth and material power has led it to neglect the fundamental role of the state in Indonesian politics.

This chapter challenges the oligarchy thesis, arguing that power continues to reside within Indonesia's state and political institutions in the post-New Order period. What is more, the overwhelming majority of figures populating these institutions represent "old interests," as the oligarchy thesis suggests. Yet, rather

\footnotetext{
${ }^{1}$ Thanks to Iqra Anugrah, Endah Asnari, Dani Muhtada, Ronnie Nataatmadja, Muhammad Said Mallari, and Ina Parenrengi for their research assistance; to the Equality Development and Globalization Studies (EDGS) Program at Northwestern University for providing a grant for me to conduct research in Indonesia; as well as to Michele Ford, Tom Pepinsky, Elizabeth Pisani, Danny Unger, and an anonymous reviewer for helpful comments on earlier drafts. All errors are my own.

${ }^{2}$ Edward Aspinall, "A Nation in Fragments: Patronage and Neoliberalism in Contemporary Indonesia," Critical Asian Studies 45,1 (2013): 27-54.

${ }^{3}$ Richard Robison and Vedi Hadiz, Reorganising Power in Indonesia: The Politics of Oligarchy in an Age of Markets (London: Routledge, 2004); Vedi R. Hadiz, Localising Power in PostAuthoritarian Indonesia: A Southeast Asia Perspective (Stanford, CA: Stanford University Press, 2010); Jeffrey A. Winters, Oligarchy (Cambridge: Cambridge University Press, 2011); Jeffrey A. Winters, "Oligarchy and Democracy in Indonesia," this volume, pp. 11-33.
} 
than being "oligarchs," these figures are better described as "state elites." ${ }^{4}$ Elite theory has shown that some elites are indeed defined by their relationship to the means of production. Others, however, have become elites as a result of their access to other power resources, such as official positions in the government. ${ }^{5}$ In the Indonesian case, many figures consequential in politics, especially at the subnational level, are political elites rather than oligarchs. In other words, these figures resemble a Millsian "power elite" that derives strength from the commanding positions they hold within institutions rather than from material wealth. ${ }^{6}$

Drawing on insights from elite theory, ${ }^{7}$ I argue that changing relations among the elites that dominate the state apparatus have subsequently altered state-society relations in contemporary Indonesia. Recruitment, promotion, and retirement mechanisms for state elites during the New Order were all oriented towards the central government and therefore ultimately regulated by President Suharto. ${ }^{8}$ By controlling competition from within the regime (horizontal competition), as well as suppressing discontent and challenges from below (vertical competition), the New Order regime created and maintained a certain unity among state elites. ${ }^{9}$ With their political survival at stake after the collapse of the dictatorship in 1998, state elites hastily adopted various institutional changes, such as the introduction of free elections, the decentralization of power, and reforms of the party system. These changes created competition among state elites. To find allies in their battles with one another, they subsequently started to "reach out" and "reach down" in the political arena. ${ }^{10}$ As a result, state elites have become much more dependent upon "society" than during the New Order. ${ }^{11}$ At the same time, state elites continue to mediate the influence of societal groups and

${ }^{4}$ I use the plural "state elites" to indicate the fractionalization of New Order elites since 1998 rather than to suggest diversity in the socio-economic backgrounds of these figures.

${ }^{5}$ Eric Carlton, The Few and the Many: A Typology of Elites (Brookfield, VT: Scolar Press 1996), pp. 4-21. Hadiz and Robison have repeatedly emphasized that they understand the Indonesian "politico-economic oligarchy" as a distinct class whose control over the means of production has social and political consequences. See Vedi Hadiz and Richard Robison, "The Political Economy of Oligarchy and the Reorganization of Power in Indonesia," this volume, pp. 35-56. In contrast, Winters has not only a more individualistic understanding of oligarchs, but, in his view, oligarchs derive their power simply from control over material sources and not because they control a certain mode of production. See Winters, Oligarchy, p. 12.

${ }^{6}$ See C. Wright Mills, The Power Elite (New York, NY: Oxford University Press, 1956), pp. 25962. My understanding of elites is congruent with that of Winters, who says that elites emerge whenever coercive power, mobilizational power, official positions, and/or political rights are “... distributed in highly exclusive or concentrated ways." Winters, "Oligarchy and Democracy in Indonesia," p. 13.

${ }^{7}$ Richard Lachmann and Nelson Pichardo, "Making History from Above and Below: Elite and Popular Perspectives," Social Science History 18,4 (1994): 503.

8 Ross McLeod, "The Struggle to Regain Effective Government under Democracy in Indonesia," Bulletin of Indonesian Economic Studies 43,1 (2005): 367-86.

9 Michael Malley, "Resources Distribution, State Coherence, and the Changing Level of Political Centralization in Indonesia, 1950-1997" (PhD dissertation, University of WisconsinMadison, 1999), pp. 145-95.

${ }^{10}$ Michael Buehler, "Local Elite Reconfiguration in Post-New Order Indonesia: The 2005 Election of District Government Heads in South Sulawesi," Review of Indonesian and Malaysian Affairs 41,1 (2007): 119-47.

${ }^{11}$ Loren Ryter, "Their Moment in the Sun: The New Indonesian Parliamentarians from the Old OKP," in State of Authority: The State in Society in Indonesia, ed. Gerry van Klinken and Joshua Barker (Ithaca, NY: Cornell Southeast Asia Program Publications, 2009), p. 215. 
interests as a consequence of their dominant position within the state and political institutions. I argue that the new dynamics among state elites have made them receptive to the demands of societal groups, but only if these groups provide resources that help those elites gain and maintain power in Indonesian politics. Resources that elites value include access to power brokers who can mobilize the electorate, the accumulation of financial means to pay for their political battles, and coercive power.

In order to illustrate this argument, I analyze the adoption of Islamic law (shari'a) in South Sulawesi since 1998. I operationalize "political influence" as influence over policymaking at the local level for two reasons. First, local politics are the "first frontier" for studying the concentration and dispersion of state power because the exchange between the state and society is more direct in this stratum than at the national level. ${ }^{12}$ Hence, a focus on local politics can identify at an early stage the mechanisms through which boundaries between the state and society are created, sustained, and restructured. Second, some societal groups try to change the broad legal or institutional structures of a polity, such as the scope of participatory rights or the rules for party formation. However, societal groups are usually more effective at influencing politics at an intermediate level, namely by shaping public policy. ${ }^{13}$

I focus on shari'a policymaking because the adoption of Islamic law in Indonesia is one of the few tangible policy trends evident in a political system defined by clientelist rather than programmatic politics. ${ }^{14}$ In addition, the discussion over the proper role of Islamic law in politics is one of the most enduring ideological fault lines in Indonesian politics. Dating back to the constitutional debates in 1945, the shari'a debate allows for a longitudinal comparison of the political influence of different groups before and after 1998. Moreover, the groups traditionally fighting over the adoption of Islamic law have always been rooted in a relatively clearly defined class of peasant entrepreneurs and traders of non-aristocratic origin situated outside the state. ${ }^{15}$ Local shari'a policymaking is therefore a good indicator for how changing relations within the state subsequently shape relations between the state and society. Finally, South Sulawesi provides an excellent vantage point from which to examine my two arguments because the number of shari'a regulations adopted there is relatively high compared to other provinces.

The chapter begins with my analysis of the major themes within the oligarchy thesis and in the literature that has sought to challenge it, arguing that-just as the explanatory power of the oligarchy thesis is limited by its inattention to the power resources of New Order figures in the political arena-voluntarist and collectivist

12 Daniel Elazar, "The Local Dimension in Israeli Government and Politics," in Local Government in Israel, ed. Daniel Elazar and Chaim Kalchheim (Lanham, MD: University of America Press, 1988), pp. 3-40.

${ }^{13}$ Edwin Amenta, Neal Caren, Elizabeth Chiarello, and Yang Su, "The Political Consequences of Social Movements," Annual Review of Sociology 36 (2010): 290.

${ }^{14}$ Islamic law has been described as a "total discourse" that includes religious, legal, moral, and economic rules and regulations. See Brinkley Messick, The Calligraphic State (Berkeley, CA, and London: University of California Press, 1993), p. 3. I confine my analysis to the local regulations (peraturan daerah/surat bupati) with a religious connotation.

${ }^{15}$ Ruth McVey, "Review: Islam Explained," Pacific Affairs 54,2 (1981): 272; Christian Pelras, "Patron-Client Ties among the Bugis and Makassarese of South Sulawesi," in Authority and Enterprise among the Peoples of South Sulawesi, ed. Roger Tol, Kees van Dijk, and Greg Acciaioli (Leiden: KITLV Press, 2000), p. 38. 
challenges to it lack the explanatory power of an approach that privileges the dynamics within the political elite. Turning to the case study, the chapter shows first how the power of political elites is determined by a concentration of non-economic power rather than of material wealth. It then provides evidence of the increasingly competitive nature of relations among state elites since 1998, and of how this heightened competition has subsequently allowed some societal groups that were politically impotent during the New Order to gain influence. The conclusion returns to the broader theme of changing state-society relations in post-New Order Indonesia.

\section{OLIGARCHY AND BEYOND}

If we are to engage with the oligarchy thesis, it is important to isolate its key questions, concepts, and hypotheses. There are important differences between the work of Hadiz and Robison and that of Winters, which makes a structured critique of the "oligarchy thesis" challenging. However, there are elements where their approaches clearly overlap. First, they agree that economic conditions have long defined politics in Indonesia. Winters argues that the New Order regime provided a formidable tool for a small number of individuals to protect (and expand) their wealth and income. ${ }^{16}$ While defining the power base of these individuals in purely material terms, he acknowledges that strategies of wealth defense commonly include interventions in the political realm. In Hadiz and Robison's version of the oligarchy thesis, the accumulation of wealth in Indonesia occurs primarily through "control of public institutions." 17 As a consequence, "politico-economic oligarchs" directly occupy bureaucratic and political posts from where they control access to the state as well as nodal points in state-business relations.

Second, Hadiz and Robison argue that this constellation of power survived the end of the regime because the demise of the New Order resembled a palace revolt rather than a social revolution. According to these authors, since class relations established during the New Order were not affected by the collapse of the dictatorship, it was possible for the small group of people who had accumulated financial and political power to reconstitute their power within democratic institutions after $1998 .^{18}$ This also explains why the political forces of the preceding regime are able to define the way state authority and social power is transformed within the new institutions of democracy. Similarly, Winters argues that the end of the New Order regime marked a change from a sultanistic oligarchy to an untamed ruling oligarchy; in other words, a change only in how oligarchs relate to one another.

Third, new wealth and income defense strategies required in the post-1998 context have shaped politics. According to Winters, the demise of Suharto has forced oligarchs, in the name of wealth defense, to become more directly involved in

\footnotetext{
${ }^{16}$ Winters, Oligarchy, pp. 140-1.

${ }^{17}$ Hadiz and Robison, "The Political Economy of Oligarchy," p. 37. Boudreau also argues that New Order interests control access to the political system. However, he talks about "elites" rather than "oligarchs" and does not think that economic conditions define political dynamics. See Vincent Boudreau, "Elections, Repression and Authoritarian Survival in Post-transition Indonesia and the Philippines," Pacific Review 22,2 (2009): 233-53.

${ }^{18}$ Hadiz and Robison, "The Political Economy of Oligarchy."
} 
politics. In a context where "being an oligarch is closely intertwined with governing," they have thus morphed into "electoral ruling" oligarchs. ${ }^{19}$ In the electoral arena, their great wealth has allowed them to "play a central role in shaping who can contend for office." ${ }^{20}$ As a consequence, "Indonesians get to choose among options that are strongly oligarchically determined." ${ }^{21}$ Hadiz and Robison, meanwhile, argue that because the established fabric that had connected state authority, political power, and economic wealth remained largely intact, genuinely new parties are either absent or have been co-opted into the oligarchy. ${ }^{22}$ And since oligarchs dominate the political arena, there is no room for a "progressive civil society," for Indonesian civil society is fragmented and lacks the mobilizational capacity to mount an effective challenge against oligarchic rule. ${ }^{23}$ Hence, organizations and interests situated outside the state are unable to impose their will on the state and its officials and oligarchs are free to pursue a political agenda that is incompatible with truly democratic politics. ${ }^{24}$

Fourth, these modes of accumulation and exercise of power define both national and subnational politics. Although "reformers" may initially have introduced "some change" in several provinces and districts, they, too, have fallen victim to the logics of predatory politics defined by "the same kinds of social interests previously at the heart of Suharto's New Order," according to Hadiz and Robison..$^{25}$ In Hadiz's view, "little kings" (raja kecil) rig the rules of the game and form collusive networks that prevent social forces from gaining access to the local political system. ${ }^{26}$ Winters does not explicitly mention subnational oligarchs, but his account of the Jakarta gubernatorial elections suggests that he agrees that oligarchs dominate both national and subnational politics. ${ }^{27}$

Fifth and finally, reflecting the classic Marxist argument that the democratization of economic relations ought to precede elections if the latter are to be meaningful, ${ }^{28}$ Hadiz and Robison conclude that genuine democratization and political change will

\footnotetext{
${ }^{19}$ Winters , "Oligarchy and Democracy in Indonesia," pp. $15 \mathrm{ff}$.

${ }^{20}$ Ibid., p. 22.

${ }^{21}$ Ibid.

${ }^{22}$ Hadiz and Robison, “The Political Economy of Oligarchy,” p. 36.

${ }^{23}$ Ibid., p. 50.

${ }^{24}$ Hadiz and Robison backtrack from this view to some extent in their contribution to this volume (pp. 35-56). According to Winters's more nuanced theory, the presence of a democracy is perfectly compatible with the presence of an oligarchy as long as democratization and electoral politics do not interfere with the wealth-defense strategies of oligarchs. If this happens, however, oligarchs actively undermine democratic politics. See Winters, "Oligarchy and Democracy in Indonesia."

${ }^{25}$ Hadiz and Robison, "The Political Economy of Oligarchy," p. 53.

${ }^{26}$ Hadiz, Localising Power, p. 43. Some scholars have even argued that democratization and decentralization allowed New Order interests to expand and strengthen their influence. See Nankyung Choi, Local Politics in Indonesia: Pathways to Power (New York, NY: Routledge, 2011), p. 102.

${ }^{27}$ Hadiz and Robison see oligarchs dominating subnational politics while Winters sees national oligarchs at least influencing local politics through funding local elites. See Winters, "Oligarchy and Democracy in Indonesia," pp. 22-25.

${ }^{28}$ Benedict Anderson, "Elections and Participation in Three Southeast Asian Countries," in The Politics of Elections in Southeast Asia, ed. Robert H. Taylor (New York, NY: Cambridge University Press, 1998), p. 12.
} 
occur if economic change determines "new forms of production and property [that] give rise to new forces and interests." ${ }^{29}$ Similarly, Winters argues that oligarchy cannot be overcome through elections in the absence of a fairer distribution of wealth. ${ }^{30}$ To summarize, there is broad agreement that, since the events of May 1998 did not democratize class relations, Indonesian politics may have changed in style but not in substance. ${ }^{31}$

There are many possible challenges to these premises. For instance, voluntarist approaches claim that state-society relations in Indonesia are changing. Individual "decision-makers" are the drivers of this change since classes "cannot overwhelm and deny the individual's capacity for autonomous choice." ${ }^{32}$ These approaches claim that Indonesians have voted for "attractive leadership" 33 that is "both responsive and responsible" to citizens' demands at the national level. ${ }^{34}$ At the subnational level, meanwhile, the decentralization of power facilitated the emergence of "reform-minded individuals." 35 While acknowledging that such leaders are rare, these scholars observe that provinces and districts that have been blessed with such "good leadership" have seen change ranging from the inclusion of hitherto marginalized groups in political deliberations ${ }^{36}$ to the reform of tax codes in favor of private sector interests. ${ }^{37}$

But those who see "enlightened leadership" as the main catalyst for changing state-society relations struggle as much as do theorists of oligarchy when it comes to explaining power dynamics in post-1998 Indonesia. Key concepts such as "good leadership" are, if at all, poorly conceptualized, and the mechanisms and processes through which individual leaders change Indonesian politics are neither described nor explained. Hence, we learn neither how "reform-minded leaders" manage to bypass bureaucratic resistance and opposition within the state apparatus nor why only certain figures are able to act in new ways. Furthermore, the number of reformminded individuals represented in formal politics is far too small to explain the fact that state-society relations have changed across the archipelago.

Meanwhile, scholars working within a pluralist theoretical framework have mounted two lines of attack against the oligarchy thesis. "Interest group pluralists" doubt that the oligarchs are as dominant in Indonesian politics as Hadiz and Robison

${ }^{29}$ Hadiz and Robison, “The Political Economy of Oligarchy,” p. 41.

${ }^{30}$ Winters, "Oligarchy and Democracy in Indonesia," p. 12.

${ }^{31}$ Similar arguments are made by John Sidel, "The Changing Politics of Religious Knowledge in Asia: The Case of Indonesia," in The Politics of Knowledge, ed. Saw Swee-Hock and Danny Quah (Singapore: ISEAS, 2009), pp. 156-92; and Yuki Fukuoka, "Oligarchy and Democracy in Post-Suharto Indonesia," Political Studies Review 11,1 (2013): 52-64.

${ }^{32}$ R. Willam Liddle, “The Politics of Development Policy,” World Development 20,6 (1992): 796.

${ }^{33}$ Saiful Mujani and R. William Liddle, "Leadership, Party, and Religion: Explaining Voting Behavior in Indonesia," Comparative Political Studies 40,7 (2007): 844.

34 Saiful Mujani and R. William Liddle, "Personalities, Parties, and Voters," Journal of Democracy 21,2 (2010): 49.

${ }^{35}$ Arianto Patunru, Neil McCulloch, and Christian von Luebke, "A Tale of Two Cities: The Political Economy of Local Investment Climate in Solo and Manado, Indonesia," IDS Working Papers 228 (2009): 1-43.

${ }^{36}$ Sebastian Eckardt, Accountability and Decentralized Service Delivery: Explaining Performance Variation across Local Governments in Indonesia (Berlin: Nomos Verlag, 2009).

${ }^{37}$ Christian von Luebke, "The Political Economy of Local Governance: Findings from an Indonesian Field Study," Bulletin of Indonesian Economic Studies 45,2 (2009): 201-30. 
and Winters claim. They argue that after 1998, representatives from a variety of interest groups, including entrepreneurs, politically ambitious newcomers, and civil society representatives, entered politics. There, they effectively counterbalance oligarchic dominance. ${ }^{38}$ There are, however, several problems with this argument. Interest group pluralism somewhat naïvely assumes that the presence of interest groups in politics equates to political influence. In addition, there is only scant evidence that a broad range of societal interests is represented in formal Indonesian politics. Even if one believes that a broad range of interest groups have come to inhabit the legislative branch of government after 1998, many crucial decisions in Indonesian politics are not presented for legislative debate because the executive branch of government drives the policymaking process. ${ }^{39}$ The powers assigned to the president, governors, and district heads since 1998 means that those who want to retain political prominence need to connect themselves to the executive branch of government. However, rather than being home to a "very heterogeneous class" of political actors, ${ }^{40}$ the top posts of the executive branch are dominated by a single social type: a male bureaucrat who started his career during the New Order. ${ }^{41}$

Aware of these problems, "critical pluralists" have mounted a second line of attack against the oligarchy thesis, which no longer focuses on the "social foundations" of political conflict but on "policy outcomes." ${ }^{42}$ The explanatory power of the "oligarchy thesis" is weak, according to this argument, because it is unable to account for the kind of policy outcomes that have been evident in both national and local politics after 1998. Examples of policies that have undergone change include those associated with women's affairs, labor issues, ${ }^{43}$ and human rights, as well as predatory taxes and levies. While there is no space here for an in-depth analysis of concrete policies in these (and other) areas, it is clear that many of them could be interpreted as a sign of continuing oligarchic dominance. ${ }^{44}$ Even if one agrees that many policy outcomes in contemporary Indonesia cannot be explained within an

\footnotetext{
${ }^{38}$ Marcus Mietzner, "Fighting the Hellhounds: Pro-democracy Activists and Party Politics in Post-Suharto Indonesia," Journal of Contemporary Asia 43,1 (2013): 28-50.

${ }^{39}$ Anis Ibrahim, S. H. Sirajuddin, Nuruddin Hady, dan Umar Sholahuddin, Parlemen Lokal DPRD: Peran dan Fungsi dalam Dinamika Otonomi Daerah, (Malang: Setara Press, 2008), p. 27.

${ }^{40}$ Marcus Mietzner, "Oligarchs, Politicians, and Activists: Contesting Party Politics in PostSuharto Indonesia," this volume, pp. 99-116.

${ }^{41}$ Michael Buehler, "Married with Children: The Second Round of Direct Elections for Governors and District Heads Shows that Democratisation is Allowing Powerful Families to Entrench Themselves in Local Politics," Inside Indonesia 112 (April-June 2013).

${ }^{42}$ Thomas Pepinsky, "Pluralism and Political Conflict in Indonesia," this volume, p. 88.

${ }^{43}$ Teri L. Caraway and Michele Ford, "Labor and Politics under Oligarchy," this volume, pp. 139-55.

${ }^{44}$ For instance, one may argue that the higher number of women in parliament in 2009 compared to 2004 has not resulted from the struggle of women's organizations for gender parity through the introduction of a quota system, but was due to a shift from a closed-to an open-party list system in 2008. The open-party list system created disincentives for candidates to run under a party label and therefore placed a premium on "face recognition." Hence, many of the new female legislators are softcore-porn starlets, soap opera actresses, and singers. In addition, many female parliamentarians belong to families that managed to entrench themselves in politics after 1998. See Michael Buehler, "Married with Children." The higher number of female representatives in the 2009 parliament compared to previous parliaments could therefore be interpreted as indicative of the growing power of oligarchic interests in Indonesian politics.
} 
oligarchic framework, the explanatory power of a critical pluralism is hardly any stronger. Stripping pluralist theory of its core idea that governments are responding to the concerns of organized interest groups from all levels of society, critical pluralism shifts its focus to the very top of the political pecking order. The language used to describe the players shaping policymaking at both the national and local level in post-1998 Indonesia is revealing. "Allies of the regime" and "Indonesia's most extremely wealthy ... citizens" ${ }^{\prime 5}$ fight it out against one another.

Against this backdrop, critical pluralism looks in many ways more like an elite competition model of the kind I suggested earlier. However, it lacks important components, which an elite competition model incorporates. For instance, its focus on policy outcomes neglects a thorough analysis of power constellations at the beginning of the policymaking process. This not only poses the danger of producing ex post facto explanations of policies, ${ }^{46}$ but, more important, it risks ignoring important players altogether. For instance, Thomas Pepinsky's take on pluralism leaves the state entirely untheorized, and fails to deal with such important issues as the background of figures inhabiting the government, dynamics between them, and the sequence in which change unfolds.

Finally, proponents of state-in-society approaches argue that change in Indonesia is unfolding from the bottom up through collective action and "popular agency." ${ }^{47}$ These scholars see the state as a relatively limited actor that competes with groups in society for influence and political hegemony. ${ }^{48}$ They argue that societal groups have reclaimed authority at the "street level" ${ }^{49}$ by holding demonstrations and protests. ${ }^{50}$ Like interest group pluralists, many of these scholars also claim that the demise of the New Order has allowed "new men" to occupy state office. ${ }^{51}$ Yet, in fact, civil society is fragmented, ${ }^{52}$ and many nongovernmental organizations remain poorly organized..$^{53}$ Moreover, many of these early studies did not specify the mechanisms through which this weak and fragmented civil society imposes its agenda onto the

\footnotetext{
${ }^{45}$ Pepinsky, "Pluralism and Political Conflict in Indonesia," pp. 91, 92.

${ }^{46}$ See, for instance, Ryan Tans, "Mobilizing Resources, Building Coalitions: Local Power in Indonesia," Policy Studies 64 (Honolulu, HI: East-West Center, 2012), pp. 1-17.

${ }^{47}$ Danielle N. Lussier and M. Steven Fish, "Indonesia: The Benefits of Civic Engagement," Journal of Democracy 23,1 (2012): 70-84; Gerry van Klinken, "The Maluku Wars: Bringing Society Back In," Indonesia 71 (April 2001): 1-26; Marcus Mietzner, "Indonesia's Democratic Stagnation: Anti-reformist Elites and Resilient Civil Society," Democratization 19,2 (2012): 209_ 29; Edward Aspinall, "Popular Agency and Interests in Indonesia's Democratic Transition and Consolidation," this volume, pp. 117-37.

${ }^{48}$ Joel Migdal, State in Society: Studying How States and Societies Transform and Constitute One Another (Cambridge: Cambridge University Press, 2001).

${ }^{49}$ Joshua Barker, "Negara Beling: Street-Level Authority in an Indonesian Slum," in State of Authority: The State in Society in Indonesia, ed. van Klinken and Barker, pp. 47-72.

${ }^{50}$ Caraway and Ford, "Labor and Politics under Oligarchy."

51 Syarif Hidayat and Gerry van Klinken, "Provincial Business and Politics," in State of Authority: The State in Society in Indonesia, ed. van Klinken and Barker, pp. 149-62; Jacqueline Vel, "Pilkada in East Sumba: An Old Rivalry in a New Democratic Setting," Indonesia 80 (October 2009): 80-107.

${ }^{52}$ Aspinall, “A Nation in Fragments,” pp. 27-54.

${ }^{53}$ Hans Antloev, Derick W. Brinkerhoff, and Elke Rapp, "Civil Society Capacity Building for Democratic Reform: Experience and Lessons from Indonesia," Voluntas 21,3 (2010): 417-39.
} 
state to effect change from below. ${ }^{54}$ Finally, "civil society" is not broadly represented in Indonesian formal politics, a fact some state-in-society scholars readily admit. ${ }^{55}$

Addressing such flaws in earlier research, more recent studies have argued that subaltern groups, despite their fragmentation and their lack of representation in formal politics, have nevertheless changed politics from below. For instance, Edward Aspinall argues that a fragmented civil society has become influential in politics because "[p]olitical pressure exerted ... through mobilization ..." shaped policymaking in the context of "the rise of competitive elections." ${ }^{56}$ These dynamics result in policy outcomes the oligarchy theory cannot explain. ${ }^{57}$

Such an interpretation of change in Indonesian politics is problematic for several reasons. Most important, the influence of groups from below is contingent on elite conflict. In other words, the "networks and clusters of actors that connect [the] ruling elite with activist groups and coalitions, providing ... conduits for policy influence from below ${ }^{\prime \prime 58}$ have emerged and gained importance as a consequence of heightened competition among state elites. Only an elite competition model that locates the trigger for social change at the apex of the political structure can explain, for instance, why organized labor "has not seen a radical expansion of ... political power [after 1998]" ${ }^{\prime 59}$ but has nevertheless gained some influence over policymaking. If elite competition were absent, labor would have been unlikely to have gained more influence.

An elite competition model not only better explains the sequence in which change unfolds and why societal actors have gained influence without commensurate improvements in capacity compared to the New Order, but also illuminates the specificities of policymaking in contemporary Indonesia. For instance, the elite competition model reveals that Indonesia's many local healthcare schemes are driven by incumbents rather than class mobilization, as collectivist approaches have acknowledged. ${ }^{60}$ An elite competition model can also explain better than collectivist approaches why the influence of most societal groups is confined to the agenda-setting stage of the policy cycle. ${ }^{61}$

To summarize, an approach that sees changing relations among state elites as explaining changes in state-society relations thus both challenges the oligarchy thesis and better explains why and in what order change has occurred than either the voluntarist or collectivist approach do. In contrast to oligarchy theory, such an approach acknowledges that many players who influence policymaking do so based

\footnotetext{
${ }^{54}$ Mietzner, “Indonesia's Democratic Stagnation," pp. 9-14; Lussier and Fish, “Indonesia," pp. 70-84.

${ }^{55}$ For example, Aspinall, "Popular Agency and Interests," shows that sixteen years after the demise of the New Order, there is no "embedded institutional power for labor ... " (p. 128).

${ }^{56}$ Ibid., p. 119.

${ }^{57}$ Caraway and Ford, "Labor and Politics under Oligarchy," make a similar argument.

${ }^{58}$ Aspinall, "Popular Agency and Interests," p. 124.

${ }^{59}$ Ibid., p. 129.

${ }^{60}$ Ibid., p. 130.

${ }^{61}$ Aspinall, "Popular Agency and Interests," and Caraway and Ford, "Labor and Politics under Oligarchy," mention on several occasions that services are promised but rarely delivered, while policies are often adopted but patchily implemented. Overall, societal groups seem to have become most influential at the agenda-setting stage of the policy cycle, which is what we would expect according to the elite competition model as outlined at the beginning of this chapter.
} 
on their political rather than economic power. Change in state-society relations has therefore been possible without change in broader economic structures. An elite competition model also addresses the failure of voluntarist accounts to acknowledge that it is not "new men" but, in fact, "old elites" socialized and politicized during the authoritarian New Order who for the first time in their careers are conducting surveys to sound out their popularity, employing new campaign tactics, and spending months on dusty roads campaigning in remote villages. Likewise, the acknowledgement that change began at the top and radiated downward explains better than collectivist approaches the timing and extent of influence from below. Political change is contingent on elite conflict since societal groups became more influential after competition among state elites had increased. Furthermore, an elite competition model explains why some groups but not others have managed to take advantage of elite competition, thereby revealing the limits of "pressure from below." Since state elites continue to dominate formal politics, they mediate the influence of societal groups. Groups gain influence only if they provide state elites with resources the latter deem useful for accumulating and maintaining power. Those that do not provide such resources may mobilize but are unlikely to gain political influence.

\section{SHARI'A POLICYMAKING IN SOUTH SULAWESI}

The case study of subnational shari'a policymaking illustrates the distinctiveness of an approach that centers on dynamics among state elites and how these dynamics subsequently affect state-society relations. Moreover, by stepping outside of the Jakarta-centric study of Indonesia that has so preoccupied the analysis of oligarchy, this approach reveals where most important changes in post-Suharto Indonesian politics are occurring.

A close-knit aristocracy has long dominated politics in South Sulawesi province. While mythical conceptions of the hierarchical order of society, control over syncretist forms of Islam, and intermarriage among the noble families of South Sulawesi strengthened the position of the aristocracy vis-à-vis commoners, it was mainly economic conditions that determined the political power of the aristocracy over ordinary people. For centuries, the main source of aristocratic political power was an appanage system of landownership that became increasingly exploitative after the Kingdom of Bone, a land-based court without much stake in sea-trade activities, rose to power in $1667 .{ }^{62}$ The aristocracy's economic dominance came under pressure after the Dutch colonial government took control of "a large part of the 'regalia lands' (tanah arajang) and 'privileged lands' (tanah ongko)." ${ }^{63}$ The income the nobility obtained from their landholdings was successively reduced in the following decades so that, by the 1920s, accountability reports submitted by outgoing Dutch officials to the colonial government, the memories van overgave, stressed that the local aristocracy had only a few large landholdings left and that only a few peasants in South Sulawesi were actually landless. ${ }^{64}$

${ }^{62}$ Burhan Djaber Magenda, "The Surviving Aristocracy in Indonesia: Politics in Three Provinces of the Outer Islands" (PhD dissertation, Cornell University, 1989), pp. 548-55; Pelras, "Patron-Client Ties," p. 38.

${ }^{63}$ Pelras, "Patron-Client Ties," p. 38.

${ }^{64}$ Ibid., p. 36. 
The economic decline of the local aristocracy worked to the advantage of a commercial class of rich peasants and rice traders of non-aristocratic background. Over time, many of these commoners replaced the nobles as agricultural patrons (punggawa allaonrumang), and from this situation, they branched out into other sectors of the economy. ${ }^{65}$ Many of these new-wealth elites organized under the banner of religious organizations such as the modernist Muhammadiyah. Opening its first branch in the provincial capital Makassar in 1926, Muhammadiyah's decisive anti-aristocratic tone and its message of upward social mobility based on merit and personal achievements made the organization an ideal vehicle for these rice traders and landowners to seek more influence in the rigidly structured society of South Sulawesi.

The cleavage between the ruling aristocracy, members of which practiced mixed forms of Islam, and non-aristocratic landowners and rice traders attracted to more purist strains of Islam became even more pronounced after the outbreak of a rebellion. Guerrilla units that had fought for Indonesia's independence in South Sulawesi demanded their incorporation into the army after 1949. After the national government refused to accommodate these guerrilla groups, their leaders revolted. Initially, the rebellion in South Sulawesi attracted many aristocrats who had fought for independence and now wanted to be rewarded with positions in the Indonesian army and bureaucracy. However, the rebel movement split in 1953 after leader Kahar Muzakkar pledged allegiance to the Darul Islam rebellion, which had been fighting for a state based on Islamic law in West Java since 1948. After 1953, the national government provided most aristocrats with local government positions, thereby effectively terminating their resistance to the republic.

The Darul Islam rebellion under the Muzakkar leadership, however, continued for another decade, weakening the economic position of the aristocracy further. Most noblemen fled to the cities of South Sulawesi, which isolated them from their landholdings and trading points. Without access to these assets, they were forced to sustain the followers that had come with them to the cities from funds they had accumulated before the rebellion. After the Indonesian army had killed Muzakkar in 1965 , the aristocrats realized that "[t]he establishment of security was ... of no assistance to them, since the traditional forms of government, as well as the incomes attached to them, had been abolished in the meantime." ${ }^{66}$ Their economic situation worsened further when the national government distributed land to poor peasants across the province under the Land Reform Act, which had been adopted nationwide in 1960 but was implemented in the province only after 1965 due to the rebellion. By the 1970s, 60 percent of the peasants in South Sulawesi owned the land on which they worked, while 40 percent were share tenants, approximately only a quarter of whom cultivated land owned by the local nobility. ${ }^{67}$

Although reliable data on landownership patterns in post-1998 South Sulawesi are not available, it is clear that the majority of people continue to work as relatively independent subsistence farmers. ${ }^{68}$ Yet, despite material resources becoming more evenly spread across the population in the province, the local aristocracy was able to

\footnotetext{
${ }^{65}$ Ibid., p. 37.

${ }^{66}$ Ibid., p. 38.

${ }^{67}$ Makaliwe, "An Economic Survey of South Sulawesi," Bulletin of Indonesian Economic Studies 5,2 (1969): 18-20.

${ }^{68}$ Badan Pusat Statistik, Sulawesi Selatan Dalam Angka (BPS: Makassar 2004), pp. 42-43.
} 
retain its political dominance under Suharto's regime because the end of the Darul Islam rebellion in 1965 coincided with the rise of the New Order. Suharto continued to reward the aristocrats who had abandoned Muzakkar with positions in the local army and the bureaucracy. ${ }^{69}$ Hence, aristocrats occupied most of the governor and district head posts in South Sulawesi throughout the New Order period. ${ }^{70}$ Since the national government appointed subnational government heads, local aristocrats understood that tight connections to Jakarta were necessary to maintain power. Having links to the local population was simply not important in the advancement of one's career.

\section{Increased Elite Competition after 1998}

As a consequence of the hierarchical nature of the New Order regime, open competition among state elites in South Sulawesi was minimal between 1965 and 1998. This changed after the fall of Suharto, when new rules were adopted that introduced elections for governors and district heads via local parliaments until 2005, and through direct elections since. Despite these institutional changes, state elites continue to dominate South Sulawesi politics. At least 45 percent of candidates competing in local elections in South Sulawesi, and at least 42 percent of the winners, are New Order academics, bureaucrats, and military personnel who had joined the state apparatus during the Suharto years (see Table 1). ${ }^{71}$

At first glance, this data seem to confirm Hadiz' reading of the continuing political dominance of New Order "interests" in local politics. ${ }^{72}$ There were very few representatives of mass organizations or other society based groups participating in these local elections, and even fewer newcomers succeeded in entering the formal political system as a member of a local legislature or a district head. Where the oligarchy thesis breaks down is in its reading of the power resources of these elites, as shown above, and how dynamics among these elites shape state-society relations. Both the indirect elections between 1998 and 2005 and the direct elections since 2005 triggered fierce competition among state elites. In South Sulawesi, there were two indirect and two direct gubernatorial elections as well as thirty-two indirect and forty-seven direct district head elections between 1998 and 2013. Almost all these elections were fiercely contested. In most elections, there were at least two viable candidates with a good chance of winning and relatively equal strength with regard to the number of votes they obtained (see Table 2). ${ }^{73}$

\footnotetext{
${ }^{69}$ Ichlasul Amal, Regional and Central Government in Indonesian Politics: West Sumatra and South Sulawesi, 1949-1979 (Yogyakarta: Gadjah Mada University Press, 1992).

${ }^{70}$ District heads control rural district governments, and mayors control municipalities. Both these entities are situated below the province in Indonesia's institutional hierarchy. For brevity's sake, I refer to district heads and districts only, unless there are dynamics distinct to mayors and municipalities.

${ }^{71}$ At least 567 candidates have been competing in South Sulawesi local government head elections since 1998. I obtained the data on the career trajectory of candidates between 1998 and 2005 from local newspaper archives. The curriculum vitae of candidates for direct elections I collected at local election commissions.

${ }^{72}$ Hadiz, "Localising Power," pp. 88-119.

${ }^{73}$ Using election data from archival research and local election commissions, I calculated the number of "effective candidates" for all the races in South Sulawesi since 1998 based on Laakso, Markku, and Rein Taagepera, "Effective Number of Parties: A Measure with Application to West Europe," Comparative Political Studies 12,1 (1979): 3-27.
} 


\section{Table 1: Background of District Head and Deputy District Head} Candidates, 1998-2013

\begin{tabular}{|c|c|c|c|c|c|c|c|c|}
\hline & \multicolumn{7}{|c|}{ South Sulawesi } \\
\hline & & Governor & $\begin{array}{c}\text { Deputy } \\
\text { Governor }\end{array}$ & $\begin{array}{l}\text { District } \\
\text { Head }\end{array}$ & $\begin{array}{l}\text { Deputy } \\
\text { District } \\
\text { Head }\end{array}$ & Mayor & $\begin{array}{l}\text { Deputy } \\
\text { Mayor }\end{array}$ & Total \\
\hline \multirow{2}{*}{ Academic } & Winner & 0 & 0 & 0 & 2 & 0 & 0 & 2 \\
\hline & Loser & 0 & 0 & 2 & 9 & 2 & 4 & 17 \\
\hline \multirow{2}{*}{ Bureaucrat } & Winner & 2 & 0 & 27 & 21 & 3 & 2 & 55 \\
\hline & Loser & 0 & 2 & 76 & 66 & 11 & 5 & 160 \\
\hline \multirow{2}{*}{$\begin{array}{l}\text { Military/ } \\
\text { Police }\end{array}$} & Winner & 0 & 0 & 3 & 0 & 0 & 1 & 4 \\
\hline & Loser & 1 & 0 & 8 & 5 & 1 & 0 & 15 \\
\hline \multirow{2}{*}{ Politician } & Winner & 0 & 2 & 1 & 5 & 0 & 0 & 8 \\
\hline & Loser & 1 & 1 & 8 & 17 & 3 & 5 & 35 \\
\hline \multirow{2}{*}{$\begin{array}{c}\text { Politician/ } \\
\text { Private } \\
\text { Sector }\end{array}$} & Winner & 0 & 0 & 7 & 4 & 0 & 0 & 11 \\
\hline & Loser & 0 & 0 & 5 & 3 & 1 & 1 & 10 \\
\hline \multirow{2}{*}{$\begin{array}{l}\text { Private } \\
\text { Sector }\end{array}$} & Winner & 0 & 0 & 6 & 2 & 6 & 2 & 16 \\
\hline & Loser & 2 & 1 & 21 & 23 & 9 & 9 & 65 \\
\hline \multirow{2}{*}{ Other } & Winner & 0 & 0 & 0 & 0 & 0 & 0 & 0 \\
\hline & Loser & 0 & 0 & 0 & 1 & 0 & 0 & 1 \\
\hline \multirow{2}{*}{ Missing } & Winner & 0 & 0 & 17 & 25 & 2 & 6 & 50 \\
\hline & Loser & 0 & 0 & 47 & 44 & 13 & 14 & 118 \\
\hline Total & & 6 & 6 & 228 & 227 & 51 & 49 & 567 \\
\hline
\end{tabular}

This newly competitive environment has shifted the focus of state elites downward and outward in the political arena: instead of lobbying superiors and pulling strings in Jakarta, state elites are now dependent on the support of ordinary people. South Sulawesi's population may be poor, but because many residents own the land on which they live, they are relatively independent compared to "locked-in" electorates in other parts of Southeast Asia, such as voters in parts of the Philippines under the control of land-based oligarchs. ${ }^{74}$ Since it is impossible to lobby every citizen individually, candidates running for local elections have had to find ways to mobilize and structure the electorate. There are many challenges that candidates must overcome to achieve these two goals, especially because many avenues available to politicians in consolidated democracies do not exist in Indonesia. Most

${ }^{74}$ James C. Scott, "Corruption, Machine Politics, and Political Change," American Political Science Review 63,4 (1969): 1146, ftn. 16. 
important, Indonesian political parties are weakly institutionalized and lack stable constituencies. Parties also have no comprehensive and well-formulated party platforms, and no money to appeal to voters. As a consequence, Indonesian politicians need to establish personal political machines to mobilize and structure the masses. ${ }^{75}$ It is against this backdrop that linkages to local power brokers and their networks have acquired new importance.

\section{Growing Interdependence between State Elites and Islamist Groups}

The three gubernatorial campaigns in South Sulawesi after 1998 exemplify the increased competition among state elites, and the growing links between candidates and Islamist groups that have emerged as a consequence of that competition. In the first gubernatorial election in South Sulawesi in 2003, the provincial parliament elected Amin Syam as governor. Syam was born in Bone district in South Sulawesi in 1945 and joined the military in 1960. He was initially stationed in West Java, but transferred to South Sulawesi a few years later to fight against the Darul Islam. Over the following decades, Syam rose through the ranks of the local military command and eventually became a major-general. He also occupied civilian posts like many military men during the New Order. He was the district head of Enrekang between 1988 and 1993 and became the head of the South Sulawesi parliament as a member of the Golkar party (Partai Golongan Karya, Party of the Functional Groups) in the final years of the New Order.

Syam announced in 2005 that he would seek reelection in 2007. In anticipation of the first direct gubernatorial election to be held in South Sulawesi province, he started to establish campaign structures across South Sulawesi. ${ }^{76}$ Syam mobilized the bureaucracy, courted the Golkar party, and established a campaign team consisting of relatives and supporters. To increase his electability, he also approached various groups with extensive networks in South Sulawesi society. In this context, Syam began to visit religious boarding schools across South Sulawesi, and also to mingle with figures from Islamist networks in 2006. ${ }^{77}$

A year before the gubernatorial elections, for instance, Syam visited the grave of Ahmad Marzuki Hasan, the founder of a radical pesantren called Darul Istiqamah. The visit was clearly a campaign event, as a large entourage of local politicians and journalists accompanied him on the visit. ${ }^{78}$ In July 2006, Syam visited the Islamist Darul Ulum Pesantren in Maros, where he praised the important contributions the school had made in the fight for the adoption of Islamic law in South Sulawesi. Syam

\footnotetext{
${ }^{75}$ Michael Buehler, "The Rising Importance of Personal Networks in Indonesian Local Politics: An Analysis of District Government Head Elections in South Sulawesi in 2005," in Deepening Democracy in Indonesia? Direct Elections for Local Leaders (Pilkada), ed. Maribeth Erb and Priyambudi Sulistiyanto (Singapore: ISEAS 2009), pp. 101-24.

${ }^{76}$ For instance, Syam hired many candidates from the 2005 district head elections to form an "expert team." He hoped to have these local notables at his disposal during the elections, according to his campaign manager. Rauf, personal communication, March 27, 2006.

${ }^{77}$ Many of these Islamist groups have direct links to the Darul Islam. After 1965, the remaining rebels established a clandestine but densely knit network of schools, foundations, and nongovernmental organizations across the province. This network survived throughout the New Order.

${ }^{78}$ Anonymous, “Pendiri Pesantren Darul Istiqamah Berpulang," Fajar, June 28, 2006, p. 26.
} 
Table 2: Number of Effective Candidates in

South Sulawesi Government Head Elections, 1998-2013

\begin{tabular}{|c|c|c|c|c|c|c|c|c|c|c|c|c|}
\hline Locality & 1998 & 1999 & 2000 & 2003 & 2004 & 2005 & 2007 & 2008 & 2010 & 2011 & 2012 & 2013 \\
\hline S. Sulawesi & NA & & & 2.59 (3) & & & $\begin{array}{c}2.86 \\
(3) \# \#\end{array}$ & & & & & $\begin{array}{c}2.2 \\
(3) \#\end{array}$ \\
\hline Bantaeng & NA & & & NA\# & & & & $3.25(4)$ & & & & $\begin{array}{c}1.4 \\
\text { (5)\# }\end{array}$ \\
\hline Barru & & & $2.1(13)$ & & & $2.59(3)$ & & & $2.95(4)$ & & & \\
\hline Bone & & NA\# & & $1.08(3)$ & & & & $\begin{array}{l}2.18 \\
\text { (3)\# }\end{array}$ & & & & $3.2(6)$ \\
\hline Bulukumba & & & $1.95(4)$ & & & $4.24(5)$ & & & $\begin{array}{c}1.98(2) \\
{[6] \# \#}\end{array}$ & & & \\
\hline Enrekang & $2.4(3)$ & & & NA & & & & 2.8(3)\# & & & & $2.3(4)$ \\
\hline Gowa & & NA & & & & $3.73(4)$ & & & $\begin{array}{l}2.05 \\
(4) \#\end{array}$ & & & \\
\hline Jeneponto & & $1.9(3)$ & & & NA & & & $\begin{array}{l}2.43 \\
\text { (6)\# }\end{array}$ & & & & $2.1(3)$ \\
\hline Makassar & & NA & & & $\begin{array}{c}1.99(2) \\
{[3]}\end{array}$ & & & $\begin{array}{l}2.04 \\
\text { (7)\# }\end{array}$ & & & & $\begin{array}{c}5.2 \\
(10)\end{array}$ \\
\hline Maros & & NA & & & & $\begin{array}{l}3.01 \\
\text { (4)\# }\end{array}$ & & & $4.02(6)$ & & & \\
\hline Palopo & & & & NA & & & & $\begin{array}{l}2.31 \\
(4) \#\end{array}$ & & & & $\begin{array}{c}2(2) \\
{[9]}\end{array}$ \\
\hline Pangkep & & NA(5) & & & & $2.3(3)$ & & & $3.48(6)$ & & & \\
\hline Pare-Pare & $2.2(3)$ & & & $\mathrm{NA}$ & & & & 3.4 (5)\# & & & & $2.9(5)$ \\
\hline Pinrang & & NA & & NA & & & & $\begin{array}{c}1.99(2) \\
{[7]}\end{array}$ & & & & $\begin{array}{c}4.3 \\
(6) \#\end{array}$ \\
\hline Selayar & & NA & & & & $4.02(5)$ & & & $\begin{array}{l}2.62 \\
\text { (3)\# }\end{array}$ & & & \\
\hline Sidrap & & + & & NA & & & & $3.8(6)$ & & & & $\begin{array}{l}2.7 \\
(7) \#\end{array}$ \\
\hline Sinjai & NA\# & & & NA & & & & $\begin{array}{l}1.94 \\
(2) \#\end{array}$ & & & & $4.2(9)$ \\
\hline Soppeng & & & NA & & & $3.16(4)$ & & & $\begin{array}{l}3.52 \\
(7) \#\end{array}$ & & & \\
\hline Takalar & & & & & & & $\begin{array}{l}3.32 \\
(4) \#\end{array}$ & & & & $4.7(7)$ & \\
\hline \begin{tabular}{|l} 
Tanah \\
Toraja \\
\end{tabular} & & & NA(5) & & & $\begin{array}{l}4.28 \\
(6) \#\end{array}$ & & & $4.41(6)$ & & & \\
\hline $\begin{array}{l}\text { Tanah } \\
\text { Toraja } \\
\text { Utara* }\end{array}$ & & & & & & & & & & $2(7)$ & & \\
\hline Luwu & & NA & & NA & & & & $2.83(4)$ & & & & $\begin{array}{l}2.4 \\
(3) \#\end{array}$ \\
\hline \begin{tabular}{|l|} 
Luwu \\
Timur** \\
\end{tabular} & & & & & & $2.96(4)$ & & & $2.4(4) \#$ & & & \\
\hline $\begin{array}{l}\text { Luwu } \\
\text { Utara*** }\end{array}$ & & NA & & & & 2.7 (3)\# & & & $2(2)$ [9] & & & \\
\hline Wajo & & NA & & NA & & & & $3.34(4)$ & & & & \begin{tabular}{|l}
3.5 \\
$(6) \#$
\end{tabular} \\
\hline
\end{tabular}

The total number of candidates appears in parentheses and the total number of candidates participating prior to second-round elections appears in square brackets. There were no local government head elections in South Sulawesi in 2001, '02, '06, and '09.

${ }^{*}$ Established in 2008; ${ }^{* *}$ Established in 2003; ${ }^{* * *}$ Established in 1999

† Appointed; \# Incumbent won; \#\# Incumbent lost; NA = Data not available 
also made a significant cash donation to the school. ${ }^{79}$ Only a few weeks later, Syam, as governor, adopted shari'a regulation No. 4/2006 to improve Quran reading skills across the province.

Syam's interest in these networks marked a clear change in political strategy. In 2001, as the head of the provincial parliament (and facing no immediate elections), Syam had refused to embrace the agenda of Islamist groups. At that time, he told the local press that as a private citizen he was sympathetic to the cause of Islamist groups, but as the head of the provincial parliament, he was against adopting shari'a. ${ }^{80}$ On the eve of Election Day in 2007, he told me: "Yes, if people reelect me, I will continue to adopt shari'a regulations in South Sulawesi province." ${ }^{81}$

Despite Syam's efforts to embrace local policy demands, it was his deputy, Syahrul Yasin Limpo, who eventually won the first direct gubernatorial election. Limpo's background and political trajectory show interesting parallels to Syam's. Limpo belongs to a military family that rose to power during the New Order. He entered the bureaucracy in Gowa district in 1980 and steadily rose through the ranks of the New Order civilian apparatus until he was appointed district head in Gowa in 1994. A member of the Golkar party since the early 1980s, and with good connections to the local parliamentarians, Limpo was elected by the local legislature for a second term in 1999. Although known for his involvement in various drug and sex scandals ${ }^{82}$ rather than for his piety, Limpo adopted his first shari'a regulation as Gowa district head in 2001. Soon after he became governor in 2007, Limpo announced his plans to run for reelection in 2013. In the following years, Limpo frequently socialized with Islamist groups across the province. In 2011, he adopted a shari'a regulation that prohibited the activities of Ahmadiyah, a heterodox Islamic group, in South Sulawesi province.

Limpo's main competitor in the 2013 gubernatorial race was the mayor of Makassar, Ilham Arief Sirajuddin. Son of Arief Sirajuddin, a New Order police lieutenant-colonel who had been district head in Gowa between 1976 and 1984, Ilham Arief Sirajuddin used his father's affiliation with the New Order state to establish various businesses, which he then managed between 1992 and 2004. The younger Sirajuddin also led various associations linked to the New Order, including the Communication Forum for the Daughters and Sons of Retired Military and Police Officers, the Association of Young Indonesian Businessmen, and South Sulawesi's Chamber of Commerce. A Golkar member since 1992, he had occupied a seat in the 1999-2004 provincial parliament for Golkar. In 2004, the parliament elected him as mayor of Makassar. In his campaign to become governor, Sirajuddin, too, approached Islamist networks. For the 2013 election campaign, he chose Aziz Kahar Muzakkar, the son of the former Darul Islam leader, as his running mate. Sirajuddin also adopted various shari'a regulations as mayor of Makassar, including the collection of religious taxes and rules concerning dress codes for schoolgirls.

\footnotetext{
${ }^{79}$ Anonymous, “Amin Syam Bantu Pesantren Rp 50 Juta,” Tribun Timur, July 27, 2006, p. 22.

${ }^{80}$ Juhannis Hamdan, "The Struggle for Formalist Islam in South Sulawesi: From Darul Islam (DI) to Komite Persiapan Penegakan Syariat Islam (KPPSI)" (PhD dissertation, Australian National University, 2006), p. 190.

${ }^{81}$ Amin Syam, personal communication, October 31, 2007.

${ }^{82}$ For instance, Limpo was arrested in the company of a female "entertainer" at the Aryaduta hotel in Makassar in 2002. The police also found a bag of shabu-shabu, a methamphetamine, in the hotel room, local newspapers reported.
} 
This brief sketch of the gubernatorial elections in South Sulawesi province after 1998 shows that they almost exclusively involved state elites, who competed against one another. It also shows that these figures, some of whom fought against Islamist groups before 1998, are now collaborating with Islamist networks because they believe that Islamist networks can provide mobilizational, financial, and coercive resources important to entice voters. Candidates have tried to gain access to pesantren networks, prayer groups, and Qur'an recitation circles in which hundreds of thousands of people meet daily across South Sulawesi. Islamist groups are gatekeepers to some of the largest of these networks. In addition, many boarding schools have mobilized their students to support the candidate endorsed by the school owner. Often, shari'a regulations have also served as a means to accumulate capital. Many shari'a regulations on religious alms have been adopted, allowing local government heads to collect considerable amounts of money they have later used for political ends. Finally, Islamist groups have provided candidates with coercive power. Local Islamist paramilitaries, many consisting of local thugs and petty criminals, frequently serve as election witnesses, intimidate voters, and act as "enforcers" for local government heads. ${ }^{83}$

The provincial patterns sketched here are mirrored at the district level. There, state elites with similar backgrounds to the candidates described above have sought to develop links to Islamist groups as a way of gaining an advantage in their competition against one another. The outcome of this growing interconnectedness parallels that at the provincial level. During the New Order, not a single shari'a regulation was in force in the province. Between 1998 and 2013, almost all districts in South Sulawesi adopted at least one shari'a regulation, amounting to forty-four such regulations in total. There have been similar developments in a number of other provinces in Indonesia. Since 1998, local state elites have adopted at least 420 shari'a regulations. ${ }^{84}$ These shari'a regulations cluster in former Darul Islam areas. There, Islamist pressure groups similar to those found in South Sulawesi have gained influence over the policymaking process as a consequence of heightened competition among state elites. ${ }^{85}$

I argued earlier that state elites mediate the influence of societal groups. In other words, state elites have only become more receptive to pressures from societal groups in places and situations where such players can provide them with resources they deem important to gain and maintain power. Groups that cannot offer such information and resources remain unable to influence local politics through state elites. This point can be demonstrated by comparing the Islamist movements described here with the Prosperous Justice Party (Partai Keadilan Sejahtera, PKS), the country's strongest and most successful Islamist party. In the late New Order, a dakwah movement emerged among the pious urban middle class. Members of this movement used the political opening in 1998 to mobilize and establish PKS, much like the local Islamist groups mentioned above that also established organizations

\footnotetext{
${ }^{83}$ For details, see Michael Buehler, “Shari'a By-Laws in Indonesian Districts: An Indication for Changing Patterns of Power Accumulation and Political Corruption," Southeast Asia Research 16,2 (2008): 165-95.

${ }^{84}$ Michael Buehler and Dani Muhtada, "The Diffusion of Shari'a Policies across Indonesia," unpublished manuscript, 2014.

${ }^{85}$ Michael Buehler, "Subnational Islamization through Secular Parties: Comparing Shari'a Politics in Two Indonesian Provinces," Comparative Politics 46,1 (2013): 63-82.
} 
after the fall of Suharto. However, due to PKS's roots in urban areas, its networks are of no use to state elites in need of clientelistic networks that are-in Indonesia as in most other Asian countries-largely a rural phenomenon. ${ }^{86}$ Consequently, local state elites have not reached out to PKS. And since PKS cannot provide state elites with resources the latter deem necessary to win elections, the party's influence over shari'a policymaking remains negligible. Immediately after 1998, PKS, too, pushed for the adoption of Islamic law at both the national and local level. Realizing its political impotence, however, the party leadership decided to abandon its shari'a platform and to adjust to the political mainstream. ${ }^{87}$ This pattern reinforces the conclusion that increased visibility and assertiveness of interest groups should not automatically be taken as a sign of their growing influence.

\section{CONCLUSION}

New Order elites continue to dominate the state, and representatives of hitherto excluded groups are rarely running in and almost never winning South Sulawesi elections (or elections in any other province). However, local politics in Indonesia is not produced by "oligarchs." It is produced by state elites who have adapted to the changing nature of post-New Order Indonesian politics by selectively reaching out to societal groups that can provide them with the resources they need to win elections.

In provinces with strong Islamist networks, the rapprochement between "the state" and "society" finds its expression in the adoption of shari'a regulations. The politics of shari'a policymaking shows that, rather than the structure of economic relations defining the possibilities for change in contemporary Indonesian politics, such opportunities are found in the interstices created by changing relations among state elites. For both Hadiz and Robison and for Winters, the fact that candidates endowed with bureaucratic power are winning most Indonesian elections is indicative of how the state continues to serve the interests of that class. However, most candidates losing elections are bureaucrats, too. This fact implies a sociology of the state that goes beyond an image of "the state" as the champion of unified class interests. The Indonesian state is not merely a condensation of existing class relations, and the nature of the state cannot be uncovered by analyzing the interests of some "dominant class" as a whole vis-à-vis society. The key explanatory variable behind changing state-society relations in Indonesia after 1998 is a political, not economic, one: the relationship among state elites.

The finding that political dynamics are now different, since the collapse of the New Order, even though economic structures have not changed significantly, is not immediately incompatible with Winters's observation that oligarchs define politics only in areas from where potential threats to their wealth and income may arise. ${ }^{88}$ The adoption of Islamic law, one could argue, is simply not of any interest to oligarchs. At the same time, however, the struggle over Islamic law in South Sulawesi (as in other parts of Indonesia) was always a proxy for a more deep-

\footnotetext{
${ }^{86}$ Dan Slater, Ordering Power: Contentious Politics and Authoritarian Leviathans in Southeast Asia (Cambridge: Cambridge University Press, 2010), p. 42.

${ }^{87}$ Michael Buehler, "Revisiting the Inclusion-Moderation Thesis in the Context of Decentralized Institutions: The Behavior of Indonesia's Prosperous Justice Party in National and Local Politics," Party Politics 19,2 (2012): 210-29.

${ }^{88}$ Winters, Oligarchy, p. 31.
} 
reaching conflict over control of resources between state elites and economic elites situated in society. The adoption of shari'a regulations thus reflects the strengthening of groups with the potential to threaten the wealth and income of current state elites. It is not a peripheral interest to those elites who control state power.

The elite competition model suggested in this chapter also better explains the contours of state-society relations in post-1998 Indonesian than do voluntarist and collectivist approaches. A focus on changing relations among "old" elites inhabiting the state explains why state-society relations are changing across the archipelago despite the lack of comprehensive elite turnover after the demise of Suharto. Rather than the presence of "reform champions," it is the competition among "old" elites that has pushed the interaction between the state and society in new directions. At the same time, the elite competition model shows that change in state-society relations occurs in a top-down rather than bottom-up manner. Societal groups have become more influential in politics only after competition between elites increased. A view of Indonesian politics that centers on the relations among state elites not only reveals the opportunities for change in state-society relations, but also its limits. State elites are primarily motivated to adopt policies to attract the support of groups they need to gain and maintain power in Indonesia's electoral democracy. Whether these policies are actually implemented is of secondary importance. Hence, groups situated in society seem to have, at best, won influence over agenda-setting and policy adoption, but lack influence over the implementation stage of the policy cycle. So long as these groups have no representatives in the formal political arena, this situation is unlikely to change, and this fact has important consequences for the quality of democracy in Indonesia. ${ }^{89}$ Moreover, due to the causal primacy of elite relations, and the dependency of these elites on the state, institutional change may quickly close the interstices through which some societal groups have managed to gain and exert political influence. ${ }^{90}$ In other words, the "deep architecture" of post1998 Indonesian politics may, in fact, not be all that deep after all.

${ }^{89}$ Buehler, “Decentralisation and Local Democracy in Indonesia," pp. 267-85.

${ }^{90}$ At the time of writing, the national parliament was discussing abolishing direct elections for governors and district heads. 